\title{
On the Epistemic Decolonization of 'Western' Education: Reflections on the History of Pedagogy
}

\author{
Phillip D. Th. Knobloch (TU Dortmund)
}

In German-speaking educational discourses, voices are increasingly being raised, which are calling for an overcoming of Eurocentric perspectives. This, however, not only raises the question of how such perspectives can be overcome, but also what it is exactly that needs to be overcome. Only when the matter of what is to be overcome has been clarified, can we discuss how this may be achieved. In what follows, these questions will be discussed with respect to the educational genre called history of pedagogy (Geschichte der Pädagogik), which has played, and still does play, a central role in the tradition of German pedagogy (cf. Knobloch, 2018).

As a first orientation on the subject, one can refer to a recent history of pedagogy, whose authors have explicitly set themselves the goal of abandoning a "specifically occidental or Eurocentric perspective" (Koerrenz et al., 2017, p. 13). According to the authors, this is to be achieved by taking at least a brief look at other parts of the world in each epoch, in addition to a classical focus on Europe (the Occident or the West). However, the authors stress that "these views often do show nothing nice" (ibid.), because the history of pedagogy "is as much a history of discoveries and even liberations as it is one of abuses and rapes" (ibid.).

While it is immediately obvious that by extending the debate to parts of the world previously ignored, the perspective is broadened, it seems rather questionable as to why the history of pedagogy outside Europe should not be 'nice', or less 'nice' than in Europe. In the first chapter, which is primarily devoted to Greek and Roman antiquity, the view is expanded also, for example, to India and China, where it focuses on Hinduism, Buddhism, Confucius and Lao Tse; in the second chapter, which deals in depth with the European Middle Ages, medieval Islam is also briefly discussed. Does this mean, then, that Hinduism, Buddhism and Islam have 'little that is nice' to offer in educational terms? We will have to presuppose that this is not what the authors meant.

For if one looks at the next two chapters, both of which deal with the early modern period, it becomes clearer as to why it is claimed that history outside Europe often does not show nice things: from "Christopher Columbus to the Bill of Rights" (ibid., p. 93) and from "the Bill of Rights to the French Revolution” (ibid., p. 135).
Thus, in the third chapter, firstly education in Protestantism and Catholicism, as well as pedagogy in the context of the Thirty Years' War is dealt with in detail, but finally - and here the view is then directed outwards so to speak - also to pedagogical developments in the context of the so-called discovery and conquest of the New World. In the fourth chapter, pedagogical relations to foreign peoples in the context of colonialism and the slave trade are discussed.

If one considers in this context that "the beginning of Europe's modernity was paid for with the blood of numerous peoples and the downfall of some cultures" (ibid., p. 123), it becomes clearer as to why such circumstances are considered to be 'not nice'. It also seems obvious that it is legitimate to call such historical debates and approaches Eurocentric, in that they ignore these 'not nice' events but instead overemphasize Europe's educational achievements.

Against this background, it seems plausible that it is not appropriate to speak of overcoming Eurocentric perspectives in the history of pedagogy if non-European countries and cultures are merely also included in the relevant approaches. Rather, it seems more appropriate to additionally include the critical discussion of 'not nice' events in the context of European colonialism. But is this really enough to overcome Eurocentric perspectives?

If we follow decolonial theory, as I propose in reference to Mignolo (2012), it must be said that this is not the case. Quite the contrary. From this perspective, precisely those historical debates should be described as Eurocentric, those that not only highlight the positive achievements of European modernity, but also address the 'not nice' aspects of the modern history of pedagogy. Can the criticism of European colonialism really be Eurocentric?

At first sight it seems surprising that precisely those types of historical treatises that deal with the modern history of pedagogy and also critically address European colonialism and the problematic events associated with it should be described as Eurocentric. This can be explained by the fact that identifying with the positively connoted achievements of modernity while rejecting the negative aspects of colonialism is, as I would like to emphasize, certainly neither a new nor a critical standpoint. Rather, this attitude or viewpoint is typical of modern European and Eurocentric thinking. 
In order to be able to make sense of this idea, it is first of all necessary to remember that modern European selfconsciousness could only develop in explicit demarcation to phenomena that were perceived as non-modern. As is well known, the demarcation to pre-modern traditions, both European and non-European, plays an important role here. In addition, modern self-understanding was also essentially constituted by the demarcation from events such as slavery and other forms of oppression and exploitation that were connected with European colonialism. For modern European thinking is characterized by being both power-critical and self-critical. If that is true however, we need to then ask 'Where is the problem?'.

Of course, identification with the Enlightenment and thinking that is critical of colonialism is not problematic per se, but only in connection with a phenomenon that decolonial theory calls coloniality. The term coloniality is used here to refer to a power complex that has its origins in modern European colonialism, but which - bearing in mind all its sociohistorical transformations - is still pervasive beyond the colonial period and into the present.

It is necessary to speak of a 'power complex', since the Europeans in their colonies attempted to exercise power over the colonies and the colonized population at various levels. These levels include politics, the economy, social and cultural life. Thus, many colonies were not only to be politically controlled and economically exploited, but also the culture, social customs and education were meant to be Europeanized or transformed to the advantage of the colonizing population. This is widely known.

The concept of coloniality posits that the global relations of power, dependence, exploitation and oppression, which were formed in the course of European expansion and European colonialism on an economic, political and cultural level, continued to exist beyond the colonial period in the narrower sense. The end of European colonial rule, for example in America, obviously did not simultaneously mean the end of the modern world system. On the contrary, European colonialism and imperialism created the basic structures on which global capitalism and all other global relations developed, always to the advantage or disadvantage of certain groups or countries, cultures and ways of life. The concept of coloniality is intended to make explicit that the origins of the post-colonial global power relations, which are still effective today, are to be found in early European colonialism.

The concept of coloniality is important not only when referring to the temporal continuity of global power relations, but above all when demonstrating a specific colonial logic that is effective in the context of this discussion - from the early colonial period to the present. This logic first becomes visible in the context of the European Enlightenment, when not only European colonial projects, but also all other forms of economic, political or cultural control and domination over other regions and countries of the world were justified with reference to the cultural and intellectual superiority of Europe. It is the Enlightenment itself that is now being used as an argument to legitimize asymmetrical power relations between Europeans and non-Europeans or, according to the very logic, between the enlightened and the non-enlightened. In this sense, asymmetric power relations are considered legitimate if they serve - according to the vocabulary of the time - to civilize the barbarians. This is, if you like, a modern educational position.

The merit of decolonial theory is that it has shown that this form of legitimizing asymmetric power relations continues a tradition and practice that was already characteristic of early European colonialism. Here, it was the so-called colonial difference that legitimized asymmetric power relations between the colonized and the colonizing. The colonized were considered to be culturally and intellectually inferior, so to speak, which is why, according to the colonial argument, they were to be assisted by the colonizers. Of course, in this historical period no reference was made to a lack of enlightenment. Rather, it was the necessity of saving souls through evangelization that was supposed to legitimize colonialism as a whole, bearing in mind all its problematic effects.

Taking Latin America as an example, it can be shown that the power relations established along the lines of colonial difference continue to exist to a considerable degree long after the end of Spanish colonial rule. This applies, for example, to the economic sphere, but also to the situation of the indigenous population in the country. With the political independence of the Latin American countries, however, the justification of the relevant power relations changed. Colonialism itself and the ways of thinking and views that are characteristic of the colonial context became a sign of cultural backwardness. Spain now became synonymous with religious fanaticism, a medieval mentality, colonial violence, cruelty, inhumanity, and ultimately a lack of enlightenment and modernity. It is no longer the cultural differences between Europeans and non-Europeans, nor those between Christianity and other religions that are decisive; what is central now is the distinction between enlightened civilization and colonial barbarism, or - to use the terms of decolonial theory - between modernity and coloniality.

Modern thinking based on the distinction between modernity and coloniality is therefore not Eurocentric because it assumes that European culture is generally superior to all other cultures. This is precisely not the case, as the early critical confrontation with Spanish colonialism and the inhuman colonial violence - one only has to think of Las Casas - shows. Rather, it must be considered Eurocentric because modernity and the Enlightenment are understood as genuinely European creations. The rest of the world, on the other hand, according to the Eurocentric view of the world, has made no intellectual contributions to modernity. 
A history of pedagogy will therefore be appropriately termed Eurocentric if it conveys the idea that modern enlightenment thinking, indeed that modern emancipatory pedagogy is the sole achievement of the West. Negative phenomena, i.e., those that can be associated with colonial violence and oppression, are strictly separated from the positive ones in this view. Typical for this Eurocentric view is the idea of a spiritual development of Europe or the West, which begins in Greek antiquity and leads through the Middle Ages to European Enlightenment. This narrative manifests the border that lies between the West and the rest, between civilization and barbarism - let's say between modernity and coloniality.

If one wants to overcome this Eurocentric view, little is gained if, for example, in a history of pedagogy that focuses on a Western history of thought, one only refers to some developments and events in the rest of the world in an unspecific way. Instead, it would have to be shown convincingly that the non-Western world has also made important contributions to modern pedagogy, indeed that Enlightenment and emancipation are not purely Western achievements. But are there any such contributions at all?

If one looks at some exemplary works on the history of pedagogy from the German-speaking area, this does not seem to be the case. For example, if one takes Heinrich Rechtmann's already older treatise on the Geschichte der Pädagogik (1969) as an example, it first deals with antiquity and the Middle Ages, then with modern times and the 19th and 20th centuries. In the section on modern times, Comenius, Rousseau, Pestalozzi, Schleiermacher and Herbart, among others, are considered significant. The socalled discovery of America is not even mentioned, a history of pedagogy outside Europe and the West does not seem to exist.

The same is true of Theo Dietrich's Geschichte der Pädagogik (1970), which covers the period from the 18th to the 20th century. European colonies and other non-Western countries play no role at all; non-Western pedagogues are not taken into account. This also applies to the Geschichte der Pädagogik (2004) by Winfried Böhm, in which the Brazilian pedagogue Paulo Freire is at least briefly mentioned.

The Geschichte der Pädagogik (2011) by Dietrich Benner and Friedhelm Brüggen also does not go beyond the West. However, the preface does reveal an emerging awareness of the problem of limitations of the view taken. The work, as explained, refers primarily to the German history of pedagogy, which is why initially only a few European contexts and thinkers such as Bacon, Comenius, Locke and Rousseau are treated, which are also considered significant for German discourses.

"Writing a pan-European history or even a historical 'world pedagogy' is not the aim of this volume. Histories of pedagogy can only exist in those cultural and historical contexts in which the discovery and invention of pedagogy took place. A world pedagogy must refer to them and is neither conceivable nor possible beyond them. It must proceed comparatively and can only compare what is already historically and systematically elaborated" (Benner/Brüggen, 2011, pp. 9-10).

But aren't there any historical-systematic works on pedagogy in the colonial and post-colonial context? Or was pedagogy neither 'invented' nor 'discovered' in these contexts?

If one wants to decolonize the history of pedagogy epistemically, i.e., to construct new narratives that overcome Eurocentric views, it is necessary to also take into account genuine contributions from the so-called non-Western world that have contributed or can contribute to the further development of modern pedagogy. With their Geschichte der Pädagogik (2017), Koerrenz et al. have certainly already taken an important step in the right direction in the sense that colonialism and the modern colonial world are addressed here at all. If we compare this work with earlier works of other writers, as we did, the great progress becomes apparent. This can at least help to overcome the Eurocentric idea that modern thinking and modern pedagogy have developed independently and isolated from developments in the rest of the world. German pedagogy has now finally, one could say, 'discovered' colonialism for itself.

The fact that colonialism is also an important topic for German pedagogy could of course also be shown if the German classics of pedagogy were to be reread through a decolonial lens. After all, European colonialism and its dark sides were of course among the most important topics of the representatives of enlightenment in educational theory. A self-critical anti-colonialism was even almost common, as can be seen, for example, in Johann Gottfried Herder's philosophy of history on education from 1774: "The more we Europeans invent means and tools to subjugate, cheat and plunder you in other parts of the world - perhaps it will be up to you to triumph one day!" (Herder, 2007, p. 103) There is thus much to be said in favour of the thesis of decolonial theory that the modern ideas of the Enlightenment and emancipation were developed in close relation to the dark sides of modern colonialism. With regard to this issue, which has hardly been considered so far in the debate, important new research results can be expected.

As was argued in this article, however, an engagement with European or Western authors who themselves deal with the issue of colonialism is not sufficient to overcome Eurocentric perspectives. Rather, it is necessary to point out and include educational contributions to enlightenment and emancipation which can be described as non-Western or nonEuropean, and which have so far been ignored in the respective discourses.

Elsewhere, I have tried to demonstrate what can be understood by such a shift in perspective, reorientation and expansion - or by such an epistemic decolonization - using 
the example of the Argentinean pedagogue Domingo Faustino Sarmiento and his major work Civilization and Barbarism (2007) (see Knobloch, 2013; 2016a; 2016b). Sarmiento is certainly one of the central figures in the history of world pedagogy, since he already in the middle of the 19th century pointed out that the successful combination of Western and non-Western identities must be understood as a basic problem of modern education.

Interpreted from the perspective of an epistemic decolonization of European or German pedagogy, it is of crucial importance that Sarmiento explicitly develops his considerations from a non-European point of view. Considering that German pedagogy has only in recent years discovered the topic of so-called hybrid identities for itself, it has become clear how backward the discussion on this topic has been in this context up to now. To understand this would be a prerequisite for opening up inner-disciplinary boundaries for the epistemic decolonization of (German) pedagogy and educational science that have so far been, in an almost incomprehensible and certainly also untenable manner, Eurocentric. Who could still deny that?

\section{References}

Benner, D., \& Brüggen, F. (2011). Geschichte der Pädagogik. Vom Beginn der Neuzeit bis zur Gegenwart. Reclam.

Böhm, W. (2004). Geschichte der Pädagogik. Von Platon bis zur Gegenwart. Beck.

Dietrich, T. (1970). Geschichte der Pädagogik in Beispielen. 18.-20. Jahrhundert. Klinkhardt.

Herder, J. G. (2007). Auch eine Philosophie der Geschichte zur Bildung der Menschheit. Reclam.

Knobloch, Ph. D. Th. (2013). Pädagogik in Argentinien. Eine Untersuchung zur Pädagogik im Kontext Lateinamerikas mit Methoden der Vergleichenden Erziehungswissenschaft. Waxmann.

Knobloch, Ph. D. Th. (2016a). Die Konstituierung der Vergleichenden Erziehungswissenschaft im kulturellen Kontext von modernity/coloniality. In M. Hummrich, N. Pfaff, İ. Dirim, \& C. Freitag (Eds.), Kulturen der Bildung. Kritische Perspektiven auf erziehungswissenschaftliche Verhältnisbestimmungen (pp. 19-28). Springer VS. https://doi.org/10.1007/978-3-658-10005-6_3

Knobloch, Ph. D. Th. (2016b). Von der Educación Popular zur dekolonialen Bildung. Über Transformationen pädagogischer Konzepte aus Argentinien und Lateinamerika. In U. Clement \& V. Oelsner (Eds.), Was Macht Schule? Schule als gestalteter Raum (pp. 47-63). Springer VS. https://doi.org/10.1007/978-3-658-11701-6_5

Knobloch, Ph. D. Th. (2018). Die Disziplin(en) der Erziehungswissenschaft(en) in Argentinien. In E. Glaser, H.-Ch. Koller, W. Thole, S. Krumme (Eds.), Räume für Bildung. Räume der Bildung. Beiträge zum 25. Kongress der Deutschen Gesellschaft für Erziehungswissenschaft (pp. 64-69). Budrich.

Koerrenz, R., Kennklies, K., Kauhaus, H., \& Schwarzkopf, M. (2017). Geschichte der Pädagogik. Schöningh.

Mignolo, W. D. (2019). Epistemischer Ungehorsam. Rhetorik der Moderne, Logik der Kolonialität und Grammatik der Dekolonialität (J. Kastner \& T. Waibel, Trans.). Turia + Kant. (Original work published 2006)

Rechtmann, H. J. (1969). Geschichte der Pädagogik. Wandlungen der deutschen Bildung. Ehrenwirth.

Sarmiento, D. F. (2007). Barbarei und Zivilisation. Das Leben des Facundo Quiroga (B. Zilly, Trans.). Eichborn. (Original work published 1845)

Recommended Citation

Knobloch, Ph. D. Th. (2020). On the epistemic decolonization of 'Western' education: Reflections on the history of pedagogy. On Education. Journal for Research and Debate, 3(7). https://doi.org/10.17899/on_ed.2020.7.5

About the Author

Phillip D. Th. Knobloch is a researcher and lecturer at TU Dortmund in the area of general education and the philosophy of education. His areas of work also include comparative education and intercultural education. His current research focuses on decolonial education and consumer aesthetic education. 